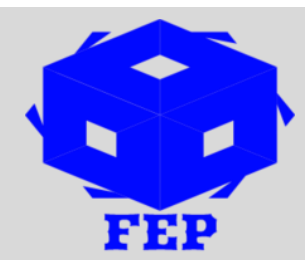

\title{
ANATOMICAL STUDIES OF LAURENCIA OBTUSA (HUDSON) LAMOUROUX (CERAMIALES) OF RHODOPHYCEAE
}

\author{
Poonam Sethi ${ }^{1}$ \& Nandhagopal $\mathrm{K}^{2}$ \\ ${ }^{1}$ Assistant Professor, Guru Nanak College(Autonomous) Chennai. India \\ ${ }^{2}$ Lecturer LNG college,Ponneri,Chennai, India
}

*Corresponding Author: Poonam Sethi

Article Received: 01-01-20

Accepted: $30-01-20$

Published: 05-02-20

Licensing Details: Author retains the right of this article. The article is distributed under the terms of the Creative Commons Attribution-Non Commercial 4.0 License (http://www.creativecommons.org/licences/by-nc/4.0/) which permits non-commercial use, reproduction and distribution of the work without further permission provided the original work is attributed as specified on the Journal open access page.

\section{ABSTRACT}

Thallus of Laurencia obtusa of Rhodophyceae was studied and detailed micromorphological evaluation was done. Morphology of the thallus has been studied to aid pharmacognostic and phytochemical evidences to aid in taxonomic species identification. Parameters presented in this paper may be proposed to establish the authenticity of this red alga and can possibly help to differentiate this alga from its other species. Since the collections were made in the month of March, Laurencia was with few gametophytic thalli . The study revealed several interesting anatomical characters and its cellular details.

Keywords: Alga,Laurencia, Marine,Micromorphological, Rhodophyceae

\section{INTRODUCTION}

India is a country with diverse medicinal plants which form the backbone of traditional systems of medicine in India, thousands of tribal communities still use folklore medicinal plants for the cure of various diseases. The great interest in the use and importance of medicinal plants in many countries has led to intensified efforts on the documentation of ethnomedical data of medicinal plants (Dhar, Dhark, Dhawan, \& Ray, 1968). The recent increase in bioactive compounds isolated from land plants, has open doors to the poorly exploited marine ecosystem which appears to be a good candidate of natural resource (Baker, 1984). The aquatic ecosystem covers about $70 \%$ of the earth's surface and India has a vast coastline of $6100 \mathrm{~km}$ supporting a rich flora of marine plants such as seaweeds, mangroves and sea grasses (Boergesen, 1934). Marine algae exhibit interesting nutritional properties in addition to their ecological properties. The results of the study suggest that the algae which are abundantly available in this ecosystem also have considerable potential of carbohydrates, 
amino acids, proteins, phenols and lipids for their use as food and pharmaceutical industry as a source in preparation of nutrient supplements, medicine and fine chemical synthesis.

\section{MATERIALS AND METHOD}

The marine Laurencia obtusa (Hudson) Lamouroux of Rhodophyceae was used as the experimental algae collected from Rameswaram, TamilNadu, India during the month of March During this period the experimental algae were usually in the gametophytic phase. Authenticated by Dr. R.Thevanathan, Presidency College, Chennai.

Herbarium specimens are available in the Herbarium Collegii Presidentiae Madrasensis of the Institution. Collections were made two days prior to new moon day every month. The collected specimens were washed twice in sterile seawater and once in antibiotic solution (containing Ampicillin, Gentamycin, Streptomycin and Chloramphenicol at a concentration of $1.0 \mu \mathrm{g} / \mathrm{mL}$ ) for 10 minutes and transferred to sealed glass specimen tubes containing sterile glass slides immersed in sterilized seawater. These were then packed in thermocol containers containing salted-ice, transferred to the laboratory within 24 hours and used for culture and further studies.

Morphological characters of the collected specimen were recorded by observation under dissection microscope. Thalli were fixed in FAA (Formalin $-5.0 \mathrm{~mL}+$ Acetic acid $-5.0 \mathrm{~mL}$ $+70 \%$ Ethyl alcohol 1- $90.0 \mathrm{~mL}$ ). After $24 \mathrm{hrs}$ of fixing, the specimens were dehydrated with graded series of tertiary-Butyl alcohol. Infiltration of the specimen was carried by gradual addition of paraffin wax (melting point $58-60^{\circ} \mathrm{C}$ ) until TBA solution attained supersaturation. The specimens were then cast into paraffin blocks.

The paraffin embedded specimens were sectioned with the help of Rotary Microtome The thickness of the sections was maintained at 10-12 $\mu \mathrm{m}$. After dewaxing, the sections were stained with Toluidine blue. Since Toluidine blue is a polychromatic stain, the staining results were remarkably good and some cytochemical reactions were also obtained. The dye rendered pink colour to the cellulose walls, blue to the lignified cells, dark green to suberin, violet to the mucilage, blue to the protein bodies etc.

\section{Photomicrographs}

Microscopic descriptions of tissues are supplemented with micrographs wherever necessary. Photographs of different magnifications were taken with Nikon Labphot 2 Microscopic Unit. For normal observations bright field was used. For the study of crystals, starch grains and lignified cells, polarized light was employed. Since these structures have birefringent property, they appear bright against dark background under polarized light. Magnifications of the figures are indicated by scale-bars.

\section{i)BOTANICAL DESCRIPTION}

\section{RESULTS}

Usually epiphytic, lower intertidal,annual,found in both northern and southern shores ofIndia.Reddish brown to red fronds with adiscoid base grows upto $150 \mathrm{mmlong}$. Axis simple branched spirally arranged giving pyramidal outline.Similar species Laurencia pyramidalis Bory deSaint Vincent ex Kutzing has more or less pyramidal outline found mainly in Scilly.

\section{ii)MACROSCOPICAL CHARACTERS}


Plants grow solitarily or in dense tufts arising from a common discoid base. Mature thalli are violet red in colour and the erect, cylindrical, compressed shoots are moderately firm. Fronds are $4-32 \mathrm{~cm}$ long, pinnately branched and branches have opposite verticillate ramuli. Apices are obtuse with depressions (Plate:I)

\section{iii)MICROSCOPICAL CHARACTERS}

In transverse sections, the axis shows 2 - 3 layers of compactly arranged cells in the margin. The central medulla is made of large colourless vertically elongated cells, rarely showing lenticular thickenings on cell walls. Cuboid or radially elongated palisade-like cells form the cortex. Fertile branchlets have apical depressions that contain a number of fertile trichoblasts arising in a spiral manner from the floor of the cavity. These are intermingled with a few sterile trichoblasts. Spermatangia occur in sub-cutellate cup shaped receptacles in the tips of fertile trichoblasts. Well separated sporangia occur in parallel zones below the truncate spines of distinct branches. Cystocarp with pericarp is partially united with adjoining vegetative cells of the branch. End cells of gonimoplast filaments functions as carposporangia.(Plate:II).

\section{DISCUSSION}

The investigation revealed anatomical characters of the alga as earlier stated by algologists (Durairatnam, 1963; Islam, 1976; Lamouroux, 1913). These characters help in identifying and authenticating this species from others prelavent in India especially the southern shores of Tamil Nadu (Agardh, 1963).

\section{References}

Agardh, J. G. (1963). Species genera et ordines algarum, 2.

Baker, J. (1984). Seaweed in pharmaceutical studies and applications. Hydrobiologia, 116/117, 29-40.

Boergesen, F. (1934a). Some Indian Rhodophyceae, especially from the shores of Presidency of Bombay IV. Kew Bull.

Dhar, M.L., Dhar, M.M., Dhawan, B.N., \& Ray, C. (1968). Screening of Indian plants for biological activity - Part I. Indian Journal of Experimental Biology, 6, 232-247.

Durairatnam, M. (1963). Some marine algae from Ceylon 2. Bulletin of the Fisheries Research Station Sri Lanka, 16, 19.

Evans, W.C., Trease, Evans. (1997). Pharmacognosy (14th Ed), Harcourt Brace and Company. Asia Pvt. Ltd. Singapore.

Islam, A.K.M. (1976). Contributions to the study of marine algae of Bangladesh. Bibliotheca Phycologia, 19.

Lamouroux, J. V. (1913). Essai sur less genres de la famille des Thalassiophytes non articulees. Annales du Muséum d'histoire naturelle, 20, 130. 


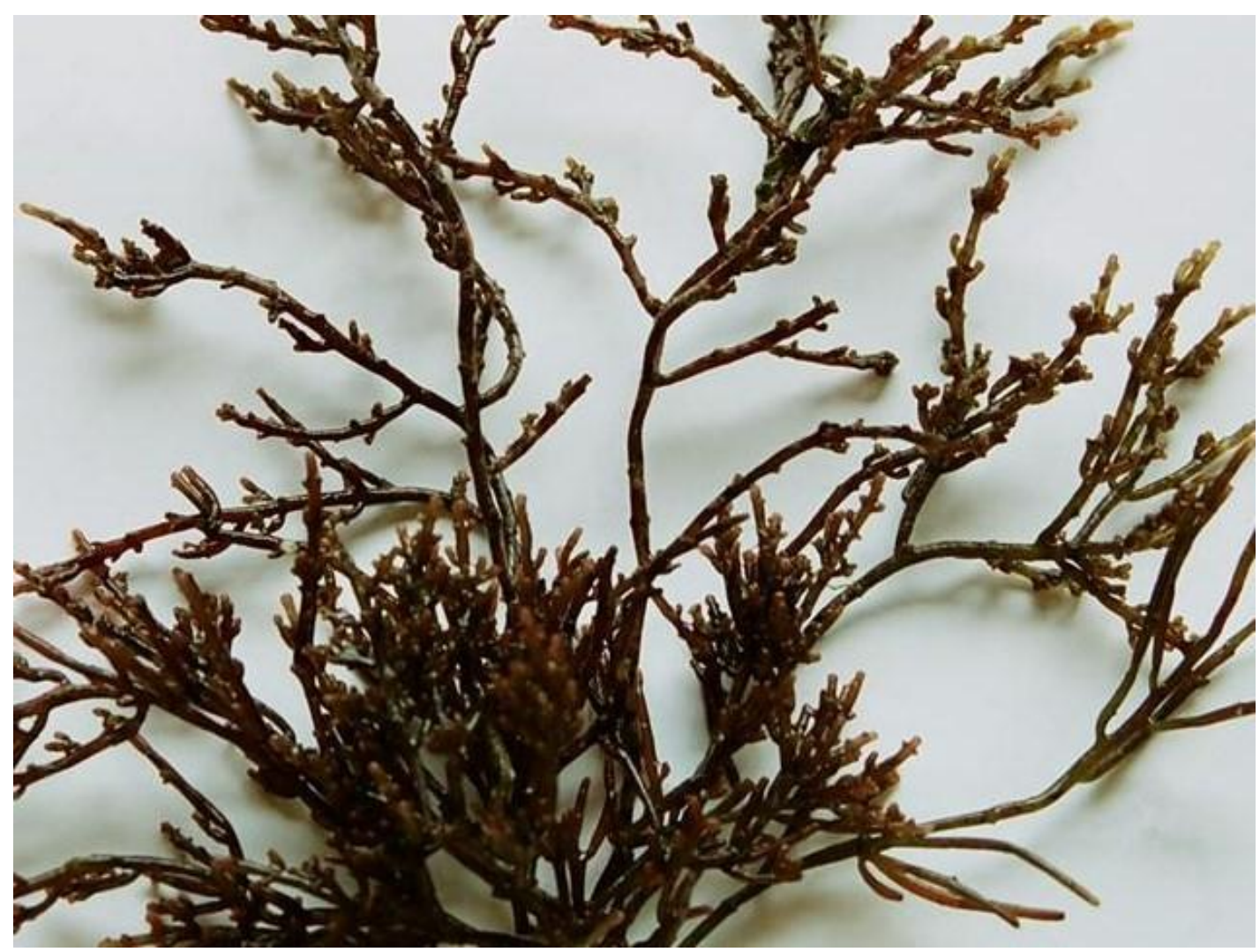

Figure 1: Plate I: Morphological Features of Laurencia Obtusa 

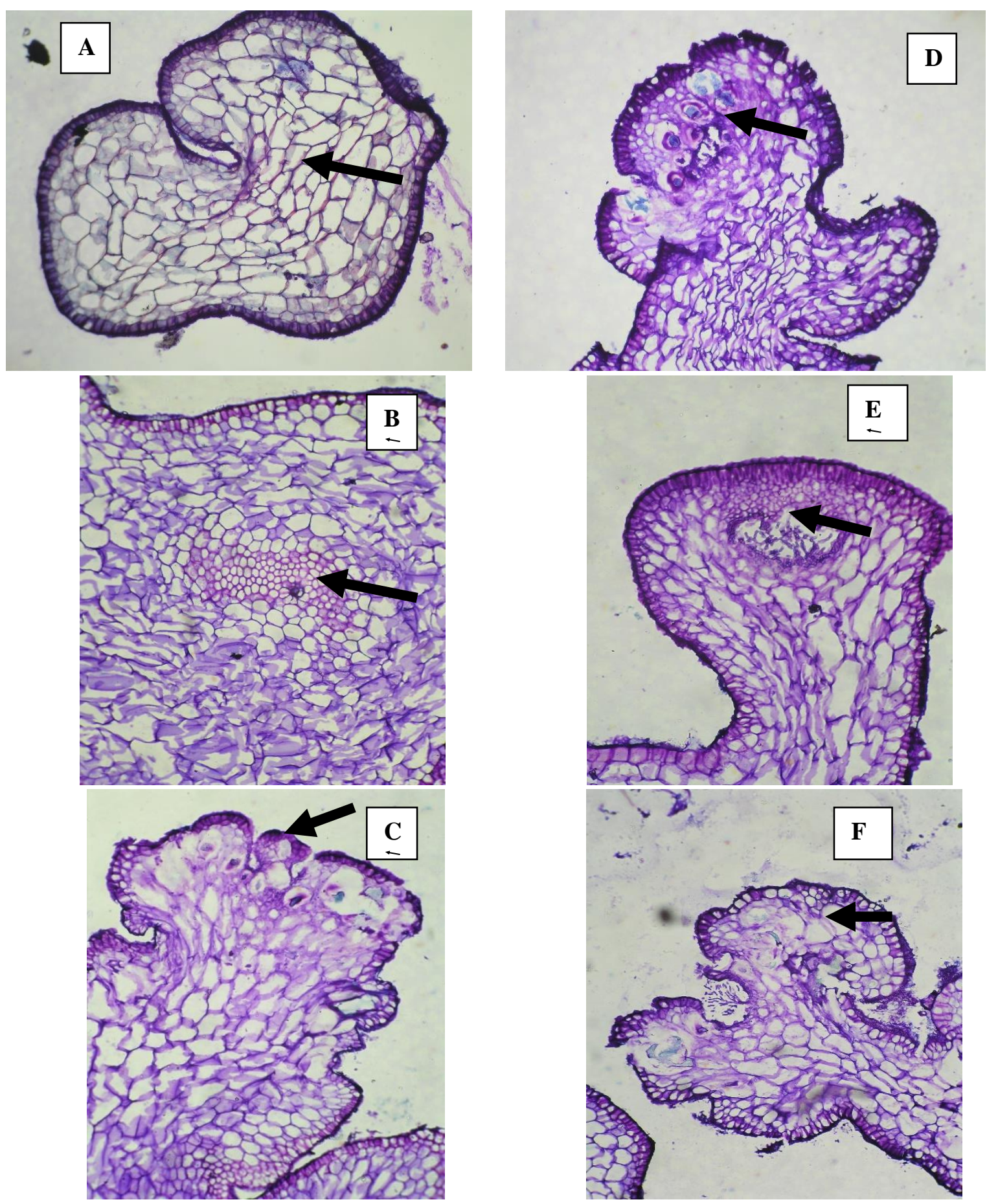

Figure 2: Plate II: Anatomical Features of Laurencia Obtusa

A. Transverse section of young axis

B. Transverse section of axis showing central medulla

C. Section of the thallus showing oogonia

D. Apical depression of axis with spermatangia

E. Transverse section of cystocarp

F. Section through tetrasporangial region 